\title{
34. UNESCO Water Chairs and Centres
}

\author{
R. Quentin Grafton \\ The Australian National University, Australia
}

The United Nations Educational, Scientific and Cultural Organisation's (UNESCO) engagement in the water sector is built on three tracks: (1) supporting scientific research that informs water-management policy, (2) facilitating education and capacity-building in the hydrological sciences, and (3) water resources assessment and management to achieve environmental sustainability (UNESCO 2014). An important way in which these objectives are achieved is through the establishment and ongoing support of UNESCO Water Chairs at higher education institutions and UNESCO Water Centres throughout the world. These research centres focus on specific subject and geographic priorities in areas of water science and policy.

The approximately 50 Water Chairs and Centres share knowledge and expertise through the International Hydrological Programme (IHP) network hosted by UNESCO. The IHP is the only intergovernmental program of the UN system that is devoted to water research, water-resources management, education and capacity-building. Other facets of the UNESCO freshwater program include: co-ordinating the publication of the annual World Water Development Report into the state of the world's freshwater resources, and support for UNESCOIHE, the world's largest international graduate water education facility, which is based in Delft, the Netherlands.

The following section presents the research and activities of five UNESCO Water Chairs and Centres. The wide range of activities in different disciplines and locations highlights the important policy-focused research that UNESCO is supporting globally. Ganoulis, Quartano, and Skoulikaris (Chapter 35) provide an overview of the work of the UNESCO Chair on Sustainable Management of Transboundary Waters and Conflict Resolution at Aristotle University of Thessaloniki, Greece. Established in 2003, this Chair conducts innovative research and education programs in the Balkans region of Europe. Working in a region affected by conflict in recent decades, this UNESCO Water Chair has supported transnational cooperation through: (1) the development of collaborative monitoring and data-sharing programs for transboundary waters, including the region's over-exploited, yet previously under-researched, groundwater aquifers; (2) the implementation of models for collaborative management of transboundary waters between water authorities in different 
countries; and, (3) the establishment of networks through which scientists from different countries collaborate on shared projects despite ongoing social and political problems, thereby acting as indirect links between their respective national institutions on transboundary water management.

Transboundary water management is also a major focus of the Centre for Water Law, Policy and Science that operates at the University of Dundee under the auspices of UNESCO. Litke and Rieu-Clarke (Chapter 36) provide an overview of the most authoritative instrument of international water law developed to date: the UN Watercourses Convention (UNWC). Adopted by the UN General Assembly in 1997, the Convention is the only global treaty on shared freshwater resources. It is principle-driven and provides a framework for rules that can be tailored to the circumstances of each international watercourse. Despite the pivotal role played by the UNWC in the development of international water law and its influence in many river basins of the world, the treaty itself is not yet in force; 31 states have ratified the treaty, four short of the required 35. As part of an international awareness campaign to secure the ratification of additional parties, the Centre for Water Law, Policy and Science developed the UNWC User's Guide. This document provides an accessible, non-technical summary of the UNWC's individual provisions and demonstrates the benefits of ratification. In addition, an online user's guide has been developed that is being updated on an ongoing basis with case studies and additional educational materials.

Addressing existing problems of scarcity in the face of burgeoning urban water demand is arguably one of the greatest challenges facing water governance. Tajrishy, Abdolghafoorian, and Abrishamchi (Chapter 37) from the UNESCO Chair in Water and Environment Management for Sustainable Cities at Sharif University of Technology consider Tehran's growing water crisis. Population growth and rising incomes are fuelling greater water consumption that is becoming increasingly unsustainable as ground and surface water resources decline. Fortunately, there are substantial unexploited opportunities to increase the efficiency of water use within the city. To illustrate possible ways forward the authors construct a detailed model of Tehran's water and wastewater system, including major sources, treatment facilities and users. They demonstrate the substantial economic gains from supplying additional recycled wastewater and treated runoff to users that do not require high-quality water, such as parks, industrial plants and construction projects. Rather than being an intractable problem, they show that Tehran's water crisis can be mitigated by appropriate investments in an integrated approach towards water and wastewater use.

The UNESCO Chair in Sustainable Water Services at Tampere University of Technology focuses on the governance and policy issues associated with water services, particularly urban and rural water supply and wastewater services (Chapter 38). In partnership with the Polytechnic of Namibia, the University 
of Nairobi and another eight institutions in industrialised and developing countries, this Chair promotes education and research on sustainable water governance and the needs of local communities. Key aspects of this research agenda include: reform processes; whether water access should be considered an economic good or a human right; good governance; the importance of history in water-sector reform; and, the commonalities across research agendas of industrialised and developing countries, such as ageing water infrastructure.

Dr R. Quentin Grafton FASSA is Professor of Economics, ANU Public Policy Fellow and Director of the Centre for Water Economics, Environment and Policy (CWEEP) at the Crawford School of Public Policy at The Australian National University. He is the Chairholder, the UNESCO Chair in Water Economics and Transboundary Water Governance and in August 2013 was appointed Executive Director at The Australian National Institute of Public Policy (ANIPP).

\section{Reference}

United Nations Educational, Scientific, and Cultural Organisation (UNESCO), 2014. 'Website of the UNESCO Freshwater Programme'. Available at: http:// www.unesco.org/new/en/natural-sciences/environment/water/. 
This text taken from Global Water: Issues and Insights by R. Quentin Grafton, Paul Wyrwoll, Chris White and David Allendes, published May 2014 by ANU Press, The Australian National University, Canberra, Australia. 